\title{
Demand models in road evacuation: a synopsis of recent contributions
}

\author{
F. Russo \& G. Chilà \\ Università degli Studi Mediterranea di Reggio Calabria, \\ DIMET - Dipartimento di Informatica, Matematica, \\ Elettronica e Trasporti, Italy
}

\begin{abstract}
After 9/11, the Indian Ocean tsunami and Katrina, the production of papers related to mobility simulation in evacuation conditions has significantly increased. Several topics have been developed, but in most cases these are implemented considering an isolated and non-system approach. The aim of this work is to present the major contributions which consider evacuation conditions, classified in respect of simulated user decisions, and to highlight the necessity of a system framework in this analysis.

Keywords: evacuation conditions, demand model.
\end{abstract}

\section{Introduction}

In evacuation conditions, demand models specified and calibrated in ordinary conditions cannot be directly applied. Various specifications can be considered in relation to the type of events, which may be classified in relation to [1-5]:

- effect in a transport system, which may be on demand, supply or demandsupply interaction;

- event kind, which can be natural or anthropogenic;

- effect in space, which can be punctual or diffuse;

- effect in time, which can be immediate or delayed.

In this work we propose a classification of literature models which simulate evacuation conditions and are demand-focused in relation to the effect in the transport system. We consider models that deal both with natural and anthropogenic disasters.

In respect on the effect in space, hazardous events will be: 
- $\quad$ events with a punctiform effect, if the event occurs in a small area and does not affect the transport infrastructure system or, if the event involves a large area, a restricted area can be defined in terms of, say, a building and a transport system can be identified within the building, connected by a transport system related to the event in the wide area [6];

- event with an extensive effect, if the event affects a vast area and is likely to influence the transport infrastructure system.

In relation to the classification above, a fire in a building is an example of a hazard with a punctiform effect. In this case, the study area coincides with the building ideas, while homogeneous areas can be considered coincident with the floors of the building and can be identified according to the subdivision, in reference to the fire regulations. In this case, demand evaluation depends on: use classification of the building, time at which users in the building leave the premises, and evacuation time [6].

If we consider an event with an extensive effect, using a town as a system of reference, the boundaries of the study area may be defined and zoning carried out for a census tract. The users present in the study area can be estimated using census data, and residences, offices, schools and shops inside the study area could be considered. The users in question could be subdivided into categories, which also depend on the reference period $[1,2]$. For example, if we consider a morning workday, the following user categories could be included:

- residents in the studying area;

- non-residents who reach the study area to work (workers);

- students;

- non-residents who occasionally reach the study area to shop or do business;

- weak users with specific mobility needs.

Instead, if we consider a night workday, categories could be residents and a small percentage of workers. User classification is useful to specify different demand models for each user category.

In respect of the effect in time, in demand analysis we consider a delayed or immediate approach, in relation to the time gap available between the time at which the dangerous event actually occurs and the time when the event starts its effects on the population. In relation to fig. 1 [1, 2, 7-9], let:

- $\mathrm{t}_{0}$ be the initial instant at which we decide to plan [10-12];

- $\mathrm{t}_{1}$, the time at which the dangerous event is expected to occur or is forecast;

- $t_{2}$, the time at which the threat occurs and becomes a dangerous event;

- $t_{3}$, the time at which the event starts its effects;

- $\mathrm{t}_{4}$, the time at which the dangerous event ceases its effects on the population.

If $\Delta_{1}+\Delta_{2}=\left(\mathrm{t}_{3}-\mathrm{t}_{1}\right) \neq 0$, we consider a delayed approach and during this gap there is the possibility of evacuating the population and thus mitigating the effect when the event occurs. In cases such as tsunamis, hurricanes, some kinds of landslide and flash floods, population evacuation could be planned and delayed in time. An example of time intervals specified for the case of a hurricane is reported in Russo and Chilà [8]. 

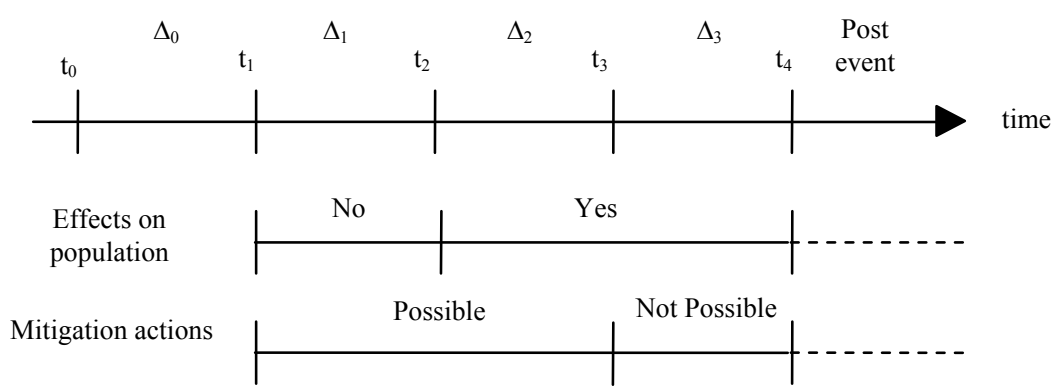

Figure 1: Evolution of a dangerous event.

In section 2 we present an overview of models found in the literature, analyzing demand evacuation for dangerous events with delayed effects in time and diffuse effects in space; in section 3 we compare the analyzed papers and highlight a general approach to simulating demand mobility in evacuation conditions.

\section{Recent literature on models simulating evacuation conditions for dangerous events}

In the last few years the production of papers related to mobility simulation in evacuation conditions has significantly increased. Several topics have been developed, in most cases related to evacuation of a building or a ship. Few of these papers deal with the problem of defining a general model able to simulate mobility evacuation of an area, considering simulation of all user decisions, such as whether or not to evacuate (generation model), when (departure time model), where to (destination model), by which transport mode or vehicle (modal choice model) and by which route (route choice model). Moreover, in the latter case, several studies focus on the optimization problem related to route choice simulation.

In this section we analyse the models in the literature which simulate demand evacuation from an extensive area, specifying the simulated user decision as to whether or not to evacuate, the destination, and by which mode and route, as evacuation operations can be divided into three main levels: at the origin (region at risk), routes and destination.

We sought to consider the recent literature, albeit evolving and with significant papers at risk of being overlooked. We analyzed and classified papers in respect of elements described below.

- The main objectives of the papers in question: we refer to the main points analyzed in the paper and then to the user's decision considered and simulated.

- Effect in space: we distinguish punctiform effects, if the study focuses on a single building, such as an office or university, and extensive effects, if the study focuses on a large area, such as a city or part of a city. 
- Time classification: we report the time at which the user's decision simulated in the paper could be classified with respect to the evolution of the dangerous event proposed in figure 1.

- Statistical and probabilistic aspects: we distinguish the statistical from the behavioral approach, which is introduced if specific hypotheses on user behavior are supposed; we point out that, for some papers which deal with planning procedures, this classification is not reported, because it is insignificant.

- Dynamic approach: we focus on dynamic aspects of the literature, as in evacuation conditions a variety of events affects the system characteristics of users and the transportation network in time. Hence the use of dynamic models is very useful and appropriate.

- Data: we summarise data used to test model in the literature.

In the following sections we report contributions simulating demand mobility in evacuation conditions and, in respect of the main objectives, on generation simulation (sec. 2.1), distribution and route choice simulation (sec. 2.2), and on relations between demand and planning procedures in emergency cases (sec. 2.3).

\subsection{Generation simulation}

In this section the recent literature simulating generation demand in evacuation conditions is synthetically described.

An extensively analyzed dangerous event with delayed effects in time is the hurricane. In many contributions, two user decisions are simulated: evacuate or not and when. These decisions are simulated by considering a statistical approach, using simple relationships such as means, rates, and distributions. For example, the most common method of estimating evacuation demand is to use participation rates in evacuation zones. These rates vary according to the severity of the storm and are based on past observed behavior. Some researchers report the use of response curve, sensitive to the characteristics of the hurricane, time of day, type and timing of evacuation order, to simulate evacuation demand. These curves have been subjectively established based on past evacuation behavior and relate the proportion evacuating to the time since issuing an evacuation order.

Baker [13] proposes an analysis of hurricane evacuation behavior considering five variables: area risk level, action by public authorities, housing, prior perception of personal risk, and storm-specific threat factors. Dow and Cutter [14] examine aspects of household evacuation decision making that potentially affect transportation planning for future evacuations. Four specific issues are considered: number of vehicles by household; the timing of evacuees' departures; distances traveled in the evacuation; and the role of information in the selection of specific evacuation routes. Wilmot and $\mathrm{Fu} \mathrm{[15]} \mathrm{assume} \mathrm{that} \mathrm{the}$ decision whether and when to evacuate is made simultaneously. They postulate that this joint decision is an issue that is considered repeatedly prior to it being taken. In other words, they suggest each household reviews the conditions 
surrounding a storm continually as it approaches, each time deciding not to evacuate, until, if a threshold is reached in their evaluation, a decision is made to evacuate at a certain time. To model this process, they propose the use of a model named, by the authors, sequential logit model. Wilmot and Mei [16] compare the relative accuracy of alternative forms of trip generation of evacuation traffic. Participation rate, logistic regression, and various forms of neural network models were estimated and tested using a data set of evacuation behavior collected in southwest Louisiana, following Hurricane Andrew. Solis et al. [17] examine a set of econometric models to analyze the determinants of household hurricane evacuation choice for a sample of 1355 households in Florida. Solis et al. [18] specify analyze four evacuation probit models to evaluate the determinants of households' evacuation behavior for each storm in the analysis (that is, Katrina SE, Wilma, Dennis and Katrina NW).

A generation model included in a general system of models is proposed in Russo and Chilà in relation to the SICURO research project $[1,2]$. This work proposed a user classification in categories, including: residents in the study area, workers, students, weak users and non-residents who occasionally reach the studying area to shopping or business. For each user category, a specific generation sub-model is proposed. The advances of this model consist in the use of SP data to calibrate models simulating evacuation conditions [19, 20]. Finally, in Russo and Chilà $[8,9]$ dynamic approaches are proposed to simulate user decisions in evacuation conditions. Among dynamic models, sequential dynamic discrete choice models [21-25] represent a special class and are proposed with sequential tests to ascertain whether current decisions are directly influenced by the most recent previous decisions, also in emergency conditions.

\subsection{Distribution and route choice simulation}

In relation to destination choice simulation, a disaggregate choice model for hurricane evacuation was developed with post-Hurricane Floyd survey data collected in South Carolina in 1999, by Cheng et al. [26]. A multinomial logit model was used to investigate the effect of risk areas in the path, or projected path, of a hurricane, and socio-economic and demographic characteristics on destination choice behavior. Models were developed for evacuees travelling to friends or relatives, or hotels or motels separately. The telephone survey of the Hurricane Floyd evacuation was conducted on behalf of the U.S. Army Corps of Engineers shortly during the storm in 1999. The data contain socio-economic information of the households responding to the survey, as well as details regarding their evacuation behavior during the hurricane. Approximately, 1800 households were surveyed in the metropolitan and surrounding areas of Charleston, Myrtle Beach and Beaufort in South Carolina.

Dixit [27] presents evacuation guidelines drawn up by the local emergency management, by testing various scenarios utilizing micro-simulation, which is extremely time-consuming and does not lend flexibility to evacuation plans. This research classifies evacuation operations into three main levels and proposes a framework to assess the whole system in its entirety. At the origin, demand dictates when to schedule evacuation orders; it also dictates the capacity required 
on different routes. These breakthroughs will provide a framework for a real time decision support system which will help emergency management officials make decisions faster and on the move. A methodology to model the effect of a recent past hurricane on the mobilization times for evacuees in an evacuation is presented, utilizing simultaneous estimation techniques.

Chen and Xiao [28] proposed a model to evacuation route construction. This paper describes: the emergency evacuation model, and the necessary conditions for optimal solution; the evacuation route construction algorithm and traffic flow assignment algorithm; simulation with numerical examples.

Pel et al. [29] specified a route choice model implementing evacuation of the metropolitan area of Rotterdam, highlighting the importance of traveler information and compliance with the evacuation model.

A model simulating path choice for emergency vehicles was proposed by Vitetta et al. [30-32] and Polimeni et al. [33, 34]. This paper defines procedures to be planned and activated in emergencies in order to allow the evacuation of less able users and designs the optimal path for emergency vehicles.

A destination model is proposed in Russo and Chilà $[1,2]$. In this case two types of models are proposed:

- a model simulating only destination choice, for different user categories;

- a model simulating mode and destination choice jointly, for different user categories.

Vitetta and colleagues propose the interaction of demand and supply in emergency conditions [35-39]; for this theme we recall also Russo and Vitetta [40].

\subsection{Planning procedure for demand simulation in evacuation conditions}

In this section we examine a few papers dealing with demand simulation in evacuation conditions in respect of general planning procedures. Urbina and Wolshon [41] summarize current evacuation management policies, methods of information exchange, and decision-making criteria. They focus mainly on current state practices, including the use of reverse flow operations and intelligent transportation systems. Moreover, they summarize current evacuation management policies, methods of information exchange, and decision-making criteria. Their paper presents the general similarities and differences in practices and gives particular attention to unique, innovative, and potentially useful practices used in individual states.

Vorst [42] focuses on user behavior in emergency conditions. In evacuation models of buildings, neighbourhoods, areas, cities and countries, important psychological parameters are not frequently used. In this paper the relevance of some important variables from disaster psychology is discussed and several phases of human behavior are defined, in respect of the subdivision proposed in figure 1.

Kang et al. [43] compare respondents' hurricane evacuation expectations with their actual behavior 2 years later during Hurricane Lili. The objectives of this study were to determine whether people's expectations about: 
- information sources and evacuation decisions correspond to their later behavior in response to a hurricane threat;

- evacuation time components correspond to the time it actually takes them during actual hurricane evacuation;

- the logistics of evacuation (choice of transportation modes, number of vehicles and trailers, destination, and type of shelter) correspond to later behavior in response to a hurricane threat.

Russo and Rindone propose guidelines to plan evacuation conditions [10] and introduce the logical framework approach in this theme [11].

Chang et al. [44] develop a decision-making tool that can be used by government agencies in planning for flood emergency logistics. A real example of planning for flood emergency logistics is presented to highlight the significance of the proposed model, which allows a rescue resource distribution system to be determined for urban flood disasters.

Chiu and Zheng [45] present a model formulation and solution for simultaneous mobilization destination, traffic assignment, and departure schedule for multi-priority groups for real-time emergency response in no-notice disasters. The presented approach addresses the decision context in which multiple emergency responses and evacuation flow groups with different destinations and varying priorities coexist in the same traffic network, within which simultaneous mobilization strategies must consider this requirement.

\section{Comparison and conclusions}

In this work we presented a synopsis of recent contributions dealing with evacuation simulation. In tables $1-3$ the various papers are listed and classified according to the elements described in section 2 :

- main objectives of analyzed paper;

- effect in space;

- time classification;

- statistical and probabilistic aspects;

- dynamic approach;

- data.

From examination of the tables, it emerges that:

- most of the literature focuses on simulating specific user decisions, that is, in general, the choice of whether or not to evacuate or, in some cases, the analysis and construction of route choice, especially in relation to the evacuation of individual buildings;

- much of the literature is based on a statistical approach, with no dynamic simulation of user decisions, and consider the evolution in time of user characteristics and of the dangerous event in question;

- many contributions are based on data related to hurricane evacuations and derived models are not suitable to simulate user behavior when RP data are unavailable [19]; 
Table 1: $\quad$ Literature overview (part I).

\begin{tabular}{|c|c|c|c|c|c|c|c|}
\hline Author & Year & Objective & $\begin{array}{l}\text { Effect in } \\
\text { space }\end{array}$ & $\begin{array}{c}\text { Time } \\
\text { classification }\end{array}$ & $\begin{array}{c}\text { Statistical and } \\
\text { probabilistic aspect }\end{array}$ & $\begin{array}{l}\text { Dynamic } \\
\text { approach }\end{array}$ & Data \\
\hline Baker & 1991 & $\begin{array}{l}\text { Evacuation } \\
\text { behavior in } \\
\text { relation to } \\
\text { decision to } \\
\text { evacuate or not }\end{array}$ & Extensive & $\mathrm{t}_{0}$ & / & No & $\begin{array}{c}\text { Hurricane } \\
\text { from } \\
1961 \text { (Carla) } \\
\text { to } 1989 \\
\text { (Hugo) }\end{array}$ \\
\hline Chen \& Xiao & 2008 & $\begin{array}{l}\text { Evacuation } \\
\text { route } \\
\text { construction }\end{array}$ & Extensive & $\mathrm{t}_{1}, \mathrm{t}_{2}$ & Statistic & Yes & $\begin{array}{l}\text { Numerical } \\
\text { example }\end{array}$ \\
\hline Dow \& Cutter & 2002 & Evacuate or not & Extensive & $\mathrm{t}_{0}$ & Behavioral/Statistical & No & $\begin{array}{l}\text { Data on } \\
\text { Hurricane } \\
\text { Floyd }\end{array}$ \\
\hline $\begin{array}{l}\text { Urbina \&, } \\
\text { Wolshon }\end{array}$ & 2003 & $\begin{array}{l}\text { Order and type } \\
\text { of evacuation }\end{array}$ & Extensive & $\mathrm{t}_{0}$ & Descriptive & No & $\begin{array}{c}\text { Data on } \\
\text { Hurricane } \\
\text { Georges and } \\
\text { Floyd }\end{array}$ \\
\hline Fu \& Wilmot & 2004 & $\begin{array}{l}\text { Dynamic trip } \\
\text { generation } \\
\text { model }\end{array}$ & Extensive & $t_{1}$ & Behavioral & Yes & $\begin{array}{l}\text { Data on } \\
\text { Hurricane } \\
\text { Andrew }\end{array}$ \\
\hline Wilmot \& Mei & 2004 & Trip generation & Extensive & $t_{1}$ & $\begin{array}{c}\text { Participation rate, } \\
\text { logistic regression, } \\
\text { neural network models }\end{array}$ & No & $\begin{array}{l}\text { Data on } \\
\text { Hurricane } \\
\text { Andrew }\end{array}$ \\
\hline $\begin{array}{l}\text { Charnkol \& } \\
\text { Tanaboriboon }\end{array}$ & 2006 & $\begin{array}{c}\text { Time } \\
\text { evacuating }\end{array}$ & Extensive & $t_{0-} t_{2}$ & Statistic & No & $\begin{array}{l}\text { Data } \\
\text { collected } \\
\text { from the } \\
\text { two most } \\
\text { recent } \\
\text { tsunami in } \\
\text { Thailand }\end{array}$ \\
\hline $\begin{array}{l}\text { Kang, Lindell, } \\
\text { Prater }\end{array}$ & 2007 & $\begin{array}{l}\text { Respondents' } \\
\text { hurricane } \\
\text { evacuation } \\
\text { expectations vs. } \\
\text { their actual } \\
\text { behavior. }\end{array}$ & Extensive & $\mathrm{t}_{0}$ & Statistic & No & $\begin{array}{l}\text { Data on } \\
\text { Hurricane } \\
\text { Lili }\end{array}$ \\
\hline Russo \& Chilà & 2007 & $\begin{array}{l}\text { Generation, } \\
\text { destination and } \\
\text { modal choice }\end{array}$ & Extensive & $\mathrm{t}_{0}, \mathrm{t}_{1}$ & Behavioral/Statistical & No & $\begin{array}{l}\text { SICURO } \\
\text { trial } \\
\text { evacuation } \\
\text { data }\end{array}$ \\
\hline $\begin{array}{l}\text { Russo \& } \\
\text { Rindone }\end{array}$ & 2007 & $\begin{array}{l}\text { Planning } \\
\text { procedures }\end{array}$ & Extensive & $\mathrm{t}_{0}$ & / & No & $\begin{array}{l}\text { SICURO } \\
\text { trial } \\
\text { evacuation } \\
\text { data }\end{array}$ \\
\hline $\begin{array}{l}\text { Vitetta, } \\
\text { Quattrone \& } \\
\text { Polimeni }\end{array}$ & 2007 & $\begin{array}{l}\text { Design of route } \\
\text { choice for weak } \\
\text { user }\end{array}$ & Extensive & $t_{1}, t_{2}$ & Behavioral & No & $\begin{array}{l}\text { SICURO } \\
\text { trial } \\
\text { evacuation } \\
\text { data }\end{array}$ \\
\hline $\begin{array}{l}\text { Vitetta, } \\
\text { Musolino \& } \\
\text { Marcianò }\end{array}$ & 2007 & $\begin{array}{l}\text { Demand/supply } \\
\text { interaction }\end{array}$ & Extensive & $\mathrm{t}_{1}, \mathrm{t}_{2}$ & Behavioral & Yes & $\begin{array}{l}\text { SICURO } \\
\text { trial } \\
\text { evacuation } \\
\text { data }\end{array}$ \\
\hline Chang et al. & 2007 & $\begin{array}{l}\text { Planning for } \\
\text { flood } \\
\text { emergency } \\
\text { logistics }\end{array}$ & Extensive & $\mathrm{t}_{0}$ & l & No & $\begin{array}{l}\text { Flood in } \\
\text { Taipei City } \\
\text { (Taiwan) }\end{array}$ \\
\hline Chiu \& Zheng & 2007 & $\begin{array}{c}\text { Modeling } \\
\text { destination, } \\
\text { assignment, } \\
\text { departure time }\end{array}$ & Extensive & $\mathrm{t}_{0}, \mathrm{t}_{1}$ & Operative research & No & $\begin{array}{l}\text { Numerical } \\
\text { example }\end{array}$ \\
\hline
\end{tabular}


Table 2: $\quad$ Literature overview (part II).

\begin{tabular}{|c|c|c|c|c|c|c|c|}
\hline Author & Year & Objective & $\begin{array}{l}\text { Effect in } \\
\text { space }\end{array}$ & $\begin{array}{c}\text { Time } \\
\text { classification }\end{array}$ & $\begin{array}{c}\text { Statistical and } \\
\text { probabilistic aspect }\end{array}$ & $\begin{array}{l}\text { Dynamic } \\
\text { approach }\end{array}$ & Data \\
\hline Russo \& Chilà & à 2008 & $\begin{array}{l}\text { Generation, } \\
\text { destination } \\
\text { and modal } \\
\text { choice }\end{array}$ & Extensive & $t_{0}, t_{1}$ & Behavioral & No & $\begin{array}{c}\text { SICURO trial } \\
\text { evacuation data } \\
\text { with SP } \\
\text { approach }\end{array}$ \\
\hline $\begin{array}{l}\text { Russo \& } \\
\text { Rindone }\end{array}$ & 2008 & $\begin{array}{l}\text { LFA in } \\
\text { evacuation } \\
\text { planning }\end{array}$ & Extensive & $\mathrm{t}_{0}$ & / & No & $\begin{array}{l}\text { SICURO trial } \\
\text { evacuation data }\end{array}$ \\
\hline Chen \& Xiao & 2008 & $\begin{array}{l}\text { Evacuation } \\
\text { route } \\
\text { construction }\end{array}$ & Extensive & $\mathrm{t}_{1}, \mathrm{t}_{2}$ & Statistical & Yes & $\begin{array}{l}\text { Numerical } \\
\text { example }\end{array}$ \\
\hline $\begin{array}{l}\text { Chen, Wilmot } \\
\text { \& Baker }\end{array}$ & 2008 & $\begin{array}{l}\text { Destination } \\
\text { choice }\end{array}$ & Extensive & $\mathrm{t}_{0}$ & Behavioral & No & $\begin{array}{l}\text { Survey of } \\
\text { Hurricane } \\
\text { Floyd } \\
\text { evacuation }\end{array}$ \\
\hline $\begin{array}{c}\text { Vitetta, } \\
\text { Quattrone \& } \\
\text { Polimeni }\end{array}$ & 2008 & $\begin{array}{l}\text { Algorithms } \\
\text { for path } \\
\text { design of } \\
\text { emergency } \\
\text { vehicles }\end{array}$ & Extensive & $t_{1}, t_{2}$ & Behavioral & No & $\begin{array}{l}\text { SICURO trial } \\
\text { evacuation data }\end{array}$ \\
\hline $\begin{array}{l}\text { Vitetta, } \\
\text { Musolino \& } \\
\text { Marcianò }\end{array}$ & 2008 & $\begin{array}{l}\text { Cost } \\
\text { function for } \\
\text { evacuation } \\
\text { conditions }\end{array}$ & Extensive & $\mathrm{t}_{1}, \mathrm{t}_{2}$ & Behavioral & Yes & $\begin{array}{l}\text { SICURO trial } \\
\text { evacuation data }\end{array}$ \\
\hline Dixit & 2008 & $\begin{array}{l}\text { Origin, } \\
\text { route and } \\
\text { destination }\end{array}$ & Extensive & $\mathrm{t}_{0,} \mathrm{t}_{2}$ & Statistical & Yes & $\begin{array}{l}\text { Data related to } \\
\text { several } \\
\text { hurricanes }\end{array}$ \\
\hline $\begin{array}{l}\text { Solis, Thomas } \\
\text { \& Letson }\end{array}$ & s 2009 & $\begin{array}{c}\text { Stay at } \\
\text { home or } \\
\text { evacuate to } \\
\text { a safer area }\end{array}$ & Extensive & $\mathrm{t}_{1}$ & Probabilistic & No & $\begin{array}{l}\text { Panel data on } \\
\text { Dennis, Katrina } \\
\text { and Wilma } \\
\text { hurricanes }\end{array}$ \\
\hline Russo \& Chilà & à2009 & $\begin{array}{l}\text { Modelling } \\
\text { and DSS for } \\
\text { demand }\end{array}$ & Extensive & $\mathrm{t}_{0}, \mathrm{t}_{1}$ & Behavioral/Statistical & No & $\begin{array}{c}\text { No } \\
\text { experimentation }\end{array}$ \\
\hline $\begin{array}{l}\text { Russo \& } \\
\text { Rindone }\end{array}$ & 2009 & $\begin{array}{l}\text { Modelling } \\
\text { and DSS for } \\
\text { LFA in the } \\
\text { planning } \\
\text { process }\end{array}$ & Extensive & $\mathrm{t}_{0}$ & / & / & $\begin{array}{l}\text { SICURO trial } \\
\text { evacuation }\end{array}$ \\
\hline $\begin{array}{l}\text { Solis, Thomas } \\
\text { \& Letson }\end{array}$ & s 2010 & $\begin{array}{l}\text { Stay at } \\
\text { home or } \\
\text { evacuate to } \\
\text { a safer area }\end{array}$ & Extensive & $\mathrm{t}_{0}, \mathrm{t}_{1}$ & $\begin{array}{l}\text { Probabilistic (series of } \\
\text { Probit binary model) }\end{array}$ & $\begin{array}{l}\text { No } \\
\text { (experience } \\
\text { variable } \\
\text { included) }\end{array}$ & $\begin{array}{l}\text { Data on Katrina } \\
\text { Wilma, Dennis }\end{array}$ \\
\hline $\begin{array}{c}\text { Pel, } \\
\text { Hoogendoorn } \\
\text { \& Bliemer }\end{array}$ & 2010 & $\begin{array}{l}\text { Route } \\
\text { choice } \\
\text { model }\end{array}$ & Extensive & $t_{1}, t_{2}$ & $\begin{array}{l}\text { Behavioral (Path size } \\
\text { choice model) }\end{array}$ & Yes & $\begin{array}{l}\text { Evacuation of } \\
\text { metropolitan } \\
\text { area of } \\
\text { Rotterdam }\end{array}$ \\
\hline Vorst & 2010 & Behavioral & Extensive & $\mathrm{t}_{0}$ & Statistical & $\begin{array}{l}\text { Evacuation } \\
\text { time phases }\end{array}$ & $\begin{array}{l}\text { No } \\
\text { sexperimentation }\end{array}$ \\
\hline Russo \& Chilà & à2010a & $\begin{array}{l}\text { Generation } \\
\text { model }\end{array}$ & Extensive & $\mathrm{t}_{0}, \mathrm{t}_{1}$ & Behavioral & Yes & $\begin{array}{c}\text { No } \\
\text { experimentation }\end{array}$ \\
\hline Russo \& Chilà & à2010b & $\begin{array}{c}\text { Generation } \\
\text { model }\end{array}$ & Extensive & $\mathrm{t}_{0}, \mathrm{t}_{1}$ & Behavioral sequential & Yes & $\begin{array}{l}\text { Numerical } \\
\text { example }\end{array}$ \\
\hline
\end{tabular}


Table 3: $\quad$ Literature overview (part III).

\begin{tabular}{|c|c|c|c|c|c|c|c|}
\hline Author & Year & Objective & $\begin{array}{l}\text { Effect in } \\
\text { space }\end{array}$ & $\begin{array}{c}\text { Time } \\
\text { classification }\end{array}$ & $\begin{array}{c}\text { Statistical and } \\
\text { probabilistic aspect }\end{array}$ & $\begin{array}{l}\text { Dynamic } \\
\text { approach }\end{array}$ & Data \\
\hline $\begin{array}{l}\text { Oven \& } \\
\text { Cakici }\end{array}$ & 2009 & $\begin{array}{l}\text { Simulation } \\
\text { of people } \\
\text { evacuated }\end{array}$ & Punctiform & $\mathrm{t}_{1}, \mathrm{t}_{2}$ & Behavioral & Yes & Trial evacuation \\
\hline $\begin{array}{l}\text { Tayfur \& } \\
\text { Taaffe }\end{array}$ & 2009 & $\begin{array}{c}\text { Hospital } \\
\text { evacuations }\end{array}$ & Punctiform & $\mathrm{t}_{1}, \mathrm{t}_{2}$ & Operative research & & $\begin{array}{c}\text { Data from } \\
\text { several } \\
\text { hospitals }\end{array}$ \\
\hline $\begin{array}{c}\text { Augustijn- } \\
\text { Beckers*, } \\
\text { Flacke \& } \\
\text { Retsios }\end{array}$ & 2010 & $\begin{array}{l}\text { agent-based } \\
\text { evacuation } \\
\text { simulation } \\
\text { model }\end{array}$ & Punctiform & $t_{0}-t_{2}$ & Statistic & No & $\begin{array}{c}\text { Data from a } \\
\text { Chinese } \\
\text { supermarket } \\
\text { and a university } \\
\text { in the } \\
\text { Netherlands. }\end{array}$ \\
\hline
\end{tabular}

- a few of these papers consider human factors [41], that is the psychological impact of dangerous events, in user simulation, even if many of these are related to time interval $\left[\mathrm{t}_{0}, \mathrm{t}_{2}\right]$, during which evacuation procedures start and user behavior is fundamental (no panic) to maximize the number of evacuees.

Moreover, in few models do we find system frameworks that allow more general analysis of evacuation behavior in emergency conditions.

It is important to point out that in some specific cases the demand models analyzed are unsuitable for simulating evacuation. Indeed, even if demand models specified with extensive effects in space could be used to simulate evacuation from residences or small shops, as these buildings occur over wide areas, different models must be used to simulate evacuation from schools, hospitals or building complexes. In the literature, Tayfur and Taaffe [46] adopt a deterministic optimization approach to evaluate the hospital evacuation problem. Oven and Cakici [47] propose a study concentrating on two issues: first, what method should be pursued to accurately model an evacuation problem; the second issue is an investigation of the evacuation behavior in a high-rise office building in Istanbul. Augustijn-Beckers et al. [48] analyse data obtained from two different case studies of evacuation: a Chinese supermarket and an international university in The Netherlands.

Even if evacuation plans from individual buildings must be specified, they must be consistent with the general large-scale evacuation plan. In some cases, as in the SICURO research project experimentation, we ascertained that even if a school belonging to the wider area had a good evacuation plan, it was not consistent with the instructions provided by the town's General Civil Protection Plan. This case should be avoided to optimize times and procedures in evacuation conditions.

Our future objectives will concern specific human behavior analysis within a general system of models, suitable for simulating a wide range of evacuation cases. 


\section{References}

[1] Russo F. \& Chilà, G., Domanda di trasporto in condizioni di emergenza. Modelli e metodi per la simulazione, applicazione ad un caso reale, Franco Angeli, Milan, 2007.

[2] Russo F. \& Chilà G., Safety of users in road evacuation: demand models. Proc. of Urban Transport XIII, Urban Transport and the Environment in the 21st century, Brebbia C.A. (ed.), WIT Press, Southampton, pp. 773-782, and in Urban Transport: Safety of Users in Road Evacuation, Russo F. (ed.), WIT Press, Southampton, pp. 11-20, 2007.

[3] Russo, F. \& Vitetta A., Risk evaluation in a transportation system. International Journal of Sustainable Development and Planning, 1 (2), pp. 170-191, 2006.

[4] Russo F. \& Vitetta A., The road network design problem to improve the safety during exogenous flow perturbations. Proc. of the $29^{\text {th }}$ ISATA Conference, Florence, 1996.

[5] Russo F. \& A. Vitetta, Risk in anthropic environments: methodologies for risk evaluation and exposition reduction. Environmental Health Risk III, Brebbia et al., WIT Press, Boston, 2005.

[6] Di Gangi M., Velonà P., "Safety of users in road evacuation: pedestrian outflow models in a building". In Urban Transport XIII Brebbia, C.A. (ed.), WIT Press, pp. 813-823, ISBN 978-184564-087-3 and in Urban Transport: Safety of User in Road Evacuation, Russo F. (ed.), WIT Press, pp 51-62, 2007.

[7] Russo F. \& Vitetta A., Safety of users in road evacuation: General methodology and main results. Proc. of Urban Transport XIII, Urban Transport and the Environment in the 21st century, Brebbia C.A. (ed.), WIT Press, Southampton, pp. 763-772, 2007.

[8] Russo F. \& Chilà G., Dynamic approaches to demand model in evacuation conditions. Proc. of Urban Transport XVI, Urban Transport and the Environment in the 21st century, Brebbia C.A. (ed.), WIT Press, Southampton, pp. 303-312, 2010.

[9] Russo F. \& Chilà G., A sequential dynamic choice model to simulate demand in evacuation conditions. Proc. of Risk analysis VII \& Brownfields $V$, Brebbia C.A. (ed.), WIT Press, Southampton, pp. 431-442, 2010.

[10] Russo F. \& Rindone C., Safety of users in road evacuation: planning internal processes and guidelines. Proc. of Urban Transport XIII, Urban Transport and the Environment in the 21st century, Brebbia C.A. (ed.), WIT Press, Southampton, pp. 825-834, 2007

[11] Russo F. \& Rindone C., Safety of users in road evacuation: the logical framework approach in evacuation planning. Proc. of Urban Transport $X I V$, Urban Transport and the Environment in the 21st century, Brebbia C. A. (ed.), WIT Press, Southampton, pp. 751-760, 2008.

[12] Russo F. \& Rindone C., Safety of users in road evacuation: Modelling and DSS for LFA in the planning process. Proc. of Sustainable Development and Planning $I V$, vol.1, Brebbia C.A. (ed.), WIT Press, Southampton, pp. 453-464, 2009. 
[13] Baker E.J., Hurricane evacuation behavior. International Journal of Mass Emergencies and Disasters, Vol. 6, pp. 287-310, 1991.

[14] Dow K. \& Cutter S.L., Emerging Hurricane Evacuation Issue: Hurricane Floyd and South Carolina. Natural Hazard Review, 18, 2002.

[15] Wilmot C.G. \& Fu H., A sequential logit dynamic travel demand model for hurricane evacuation. Transp. Research Record, 1882, pp. 19-26, 2004.

[16] Wilmot C.G. \& Mei B., Comparison of Alternative Trip Generation Models for Hurricane Evacuation. Natural Hazards Review, 2004.

[17] Solis D., Thomas M., Letson D., Determinants of household hurricane evacuation choice in Florida. Presentation at the Southern Agricultural Economics Association Annual Meeting, Atlanta, Georgia, January 31February 3, 2009.

[18] Solis D., Thomas M., Letson D., Determinants of household hurricane evacuation choice in Florida. Presentation at the Southern Agricultural Economics Association Annual Meeting, Atlanta, Georgia, January 31February 3, 2009.

[19] Russo F. \& Chilà G., Safety of users in road evacuation: RP vs. SP surveys in demand analysis. Proc. of Urban Transport XIV, Urban Transport and the Environment in the 21st century, Brebbia C.A. (ed.), WIT Press, Southampton, pp. 703-713, 2008.

[20] Russo F. \& Chilà G., Safety of users in road evacuation: Modelling and DSS for demand. Proc. of Sustainable Development and Planning IV, vol.1, Brebbia C.A. (ed.), WIT Press, Southampton, pp. 465-474, 2009.

[21] Gottman, J.M. \& Roy, K.A., Sequential Analysis, Cambridge University Press, New York, 1990.

[22] Russo F. \& Chilà G., Sequential models for mobility decisions: experimentation for vehicle holding choices. Proc. of the European Transport Conference 2007, Leeuwenhorst, The Netherlands, 17-19 October 2007.

[23] Russo F. \& Chilà G., Probit Sequential Model for User's Choices. Proc. of European Transport Conference 2008, Noordwiikerhout (NL), 2008.

[24] Gottman, J.M. \& Roy, K.A., Sequential Analysis, Cambridge University Press, New York, 1990.

[25] G. Chilà, Sequential methods for user choices: tests and properties applied to a panel database. Proc. of Urban Transport XIV, Urban Transport and the Environment in the 21st century, Brebbia C.A. (ed.), WIT Press, Southampton, pp. 121-131, 2008.

[26] Cheng, G., Wilmot C.G. \& R.J. Baker. A destination choice model for hurricane evacuation. Transp. Research Board Annual Meeting, 2008.

[27] Dixit V.V., Hurricane evacuation: origin, route and destination. PhD Thesis, University of Central Florida, Florida, Orlando, Florida, 2008.

[28] Chen Y., Xiao D., Emergency Evacuation Models and Algorithms. Journal of Transportation System Engineering and Information Technology, Vol. 8, 2006.

[29] Pel A.G., Hoogendoorn S.P., Bliemer M.C.J., Evacuation modeling including traveler information and compliance behavior. Science Direct, 2010. 
[30] Vitetta A., Quattrone A. \& Polimeni A., Safety of users in road evacuation: design of path choice models for emergency vehicles. Proc. of Urban Transport XIII, Urban Transport and the Environment in the 21st century, Brebbia C.A. (ed.), WIT Press, Southampton, pp. 803-812, 2007.

[31] Vitetta A., Quattrone A. \& Polimeni A., Safety of users in road evacuation: algorithms for path design of emergency vehicles, Proc. of Urban Transport XIV, Urban Transport and the Environment in the 21st century, Brebbia C.A. (ed.), WIT Press, Southampton, pp. 727-737, 2008.

[32] Vitetta A., Quattrone A. \& Polimeni A., Safety of users in road evacuation: Modelling and DSS for paths design of emergency vehicles. Proc. of Sustainable Development and Planning IV, vol.1, Brebbia C.A. (ed.), WIT Press, Southampton, pp. 485-495, 2009.

[33] Polimeni A., Quattrone A. \&Vitetta A., A tool for tracing emergency vehicles during evacuation. Proc. of Urban Transport XVI, Urban Transport and the Environment in the 21st century, Brebbia C.A. (ed.), WIT Press, Southampton, pp. 325-333, 2010.

[34] Polimeni A., Quattrone A. \& Vitetta A., An approach to designing vehicle routes in evacuation conditions. Proc. of Risk analysis VII \& Brownfields V, Brebbia C.A. (ed.), WIT Press, Southampton, pp.469-480, 2010.

[35] Vitetta A., Musolino G. \& Marcianò F.A., Safety of users in road evacuation: Supply and demand-supply interaction models for users. Proc. of Urban Transport XIII, Urban Transport and the Environment in the 21st century, Brebbia C. A. (ed.), WIT Press, Southampton, pp. 783-792, 2007.

[36] Vitetta A., Musolino G. \& Marcianò F. A., Safety of users in road evacuation: calibration of cost functions and simulation. Proc. of Urban Transport XIV, Urban Transport and the Environment in the 21st century, Brebbia C.A. (ed.), WIT Press, Southampton, pp. 715-725, 2008.

[37] Vitetta A., Musolino G. \& Marcianò F.A., Safety of users in road evacuation: Modelling and DSS for transport supply and supply-demand interaction. Proc. of Sustainable Development and Planning IV, vol.1, Brebbia C.A. (ed.), WIT Press, Southampton, pp. 475-484, 2009.

[38] Marcianò F.A., Musolino G. \& Vitetta A., A system of models for signal setting design of a signalized road network in evacuation conditions. Proc. of Urban Transport XVI, Urban Transport and the Environment in the 21st century, Brebbia C.A. (ed.), WIT Press, Southampton, pp. 313-323, 2010.

[39] Vitetta A., Musolino G. \& Marcianò F.A., Signal setting design on a road network: application of a system of models in evacuation conditions. Proc. of Risk analysis VII \& Brownfields V, Brebbia C.A. (ed.), WIT Press, Southampton, pp. 443-454, 2010.

[40] Russo F. \& Vitetta A., Reverse assignment: calibrating link cost functions and updating demand from traffic counts and time measurements. Inverse Problems in Science \& Engineering, ISSN 1741-5977 print/ISSN17415985 Taylor \& Francis DOI: 10.1080/17415977.2011.565339

[41] Urbina E. \& Wolshon B., National review of hurricane evacuation plans and policies: a comparison and contrast of state practices. Transportation Research A, vol. 37, 2003. 
[42] Vorst H.C.M., Evacuation models and disaster psychology. ScienceDirect, vol. 3, pp. 15-21, 2010.

[43] Kang J.E., Lindell M.K., Prater C.S., Hurricane Evacuation Expectations and Actual Behavior in Hurricane Lili. Journal of Applied Social Psychology, 37, 4, pp. 887-903, 2007.

[44] Chang M.S., Tseng Y.L., Chen J.W., A scenario planning approach for the flood emergency logistics preparation problem under uncertainty. Transportation Research E, pp. 737-754, 2007.

[45] Chiu Y.C. \& Zheng H., Real-time mobilization decisions for multi-priority emergency response resources and evacuation groups: model formulation and solution. Transportation Research E, pp. 710-736, 2007.

[46] Tayfur E., Taaffe K., A model for allocating resources during hospital evacuations. Computer \& Industrial Engineering, 2009.

[47] Oven V.A. \& Cakici N., Modelling the evacuation of a high-rise office building in Istanbul. ScienceDirect, 2009

[48] Augustijn-Beckers E.-W., Flacke J., Retsios B., Investigating the effect of different pre-evacuation behavior and exit choice strategies using agentbased modeling. ScienceDirect, 2010. 